\title{
Public Opinion on Involvement of Youngsters in Drug Abuse
}

\author{
Keerthana Ganapathy, Sreeya B
}

\begin{abstract}
This study uses a functional overview to examine the reasons why young people consume drugs. Drug conception were found to differ by age and gender. Targeting substances that are concluded to fulfil similar problems and addressing issues treating the substitution of one substance for another may also strengthen education and prevention efforts. Drug abuse has been a topic of interest to many professionals in the area of physical health and mental health. This research paper is to analyse the difference between the helpline for drug abuser's and gender and to find the association between major reason for drug abuse and age of the respondents. It examines research in India regarding drug abuse among youngsters and related disorders. The objective of the study is to understand the involvement of youngsters in drug abuse and to analyse the difference between the helpline for drug abuser's and the gender. For the purpose of this study is descriptive research is used to portray accurately the public opinion on involvement of youngsters in drug abuse. Convenient sampling method is used to collect the samples. 1640 samples-sample size. Independent variables are gender, age, marital status, Educational qualification, occupation, and monthly income. The dependent variables are helpline for drug abuser, reason for drug abuse, emotional problems, accidents, brain damage, risky sex, and diseases. Independent sample t test, chi square, and ANOVA are the research tools used in this research. It was found that drug abuse is increasing in todays scenario. It is better to create awareness and helplines regarding drug abuse and its recovery.
\end{abstract}

Keywords: drug, youngsters, issues, research, reason, alcohol, substance abuse, India.

\section{INTRODUCTION}

Drug abuse is a common phenomenon in the world and has made the human society as the most important social damage. Drug abuse is a nonadaptive model of drug use, which results in adverse problems and consequences, and includes a set of cognitive behavioral, and psychological symptoms. Additionally, because of its particular human and geographic highlights, has a generally high level of contamination. The World Health Organization's report in 2005 demonstrates that there are around 200 million sedative addicts on the planet, revealing the most elevated predominance and the most recurrence in the 25-multiyearage group. The beginning of medication use is frequently established in pre-adulthood, and studies demonstrate that drug misuse is frequently identified with cigarette and liquor utilization in adolescence. Results of studies show that age, being male, high-hazard behaviours, and the presence of a cigarette smoker in the family or among companions, the

Revised Manuscript Received on 14, October 2019.

Keerthana Ganapathy, B.A. L.LB. (Hons.), Saveetha School of Law, Saveetha Institute of Medical and Technical sciences (SIMATS), Chennai, Tamilnadu, India.

Dr. Sreeya B, Associate Professor, Department of Management Studies, Saveetha School of Law, Saveetha Institute of Medical and Technical sciences (SIMATS), Chennai, Tamilnadu, India. (Email: sreeyab.ss1@saveetha.com) experience of drug misuse, tendency and positive musings about smoking have association with immature cigarette smoking. Studies likewise affirm that the possibility of turning into a cigarette smoker among guys and females is practically equivalent $(11.2 \%)$; be that as it may, the pervasiveness of standard liquor utilization in guys $(22.4 \%)$ is somewhat higher than in females $(19.3 \%)$. This study shows that different age category are falling under this drug abuse.

\section{OBJECTIVES}

- To understand the involvement of youngsters in drug abuse

- To analyse the difference between the helpline for drug abuser's and the gender

- To find the association between major reason for drug abuse and age of the respondents

- To know the difference in the mean scores of level of agree ability towards effects of drug abuse among the educational qualifications

\section{LITERATURE REVIEW}

MOSES.O. IKON, SAMO, SMEH (2019) has studied through a survey method. 10 samples from political words were drawn from metropolis. Pattern of drug consumption differs. The growing number of youths involved in drugs is becoming more worrisome. YAHYA MUHAMMED BAH (2018) has deliberated about drug abuse is a global phenomenon found in most countries of the world among youth Drug misuse, youth, adverse effect and learning. The design is survey research in what population are studied by collecting and analysing that a form only a few people. Males are more in number than female in drug abuse. SINGH M, BALA N (2017) has observed that 446 adolescents got affected by drugs during the study period. Substance use is becoming common for children now a days. It is necessary to counsel and create awareness among children. A.A. GOBIR, M.N. SAMBO (2017) have discussed about the health problem due to drug usage. The results indicated that youth in the study area, there is a need for health education campaign on harmful effects of drug abuse. MONDESTER NYAKEMWA ONGWAE (2016) have studied about many academic and professional studies have reported the prevalence of drugs among young people and its costly consequences. Sample responses and scenarios from a group of American teens reflect that their perceptions of the consequences are frequently self-oriented and male centred. Their concerns are related to health, mental health, 
sexual performance, and social relations, implications for interventions. FRANCIS K.O.YOENG \& DAVID MINETA (2013) have noted that some students use marijuana drugs. It has become more common among college students. Most of the studies have clear indication of increase in usage of drug abuse among adolescents. MAGAJI (2013) have studied about For many years, various government and communities has found a new form that has evil society, and is eating deep into the productivity sector of the economy as it's directly affects the youth.The review analyses the economic implications of drug abuse on the youth and the need for strict measures to be taken to migrate the menace, there will come a time where the working age group be scarce.

\section{METHODOLOGY}

For the purpose of this study is descriptive research is used to portray accurately the public opinion on involvement of youngsters in drug abuse. Convenient sampling method is used to collect the samples. 1640 samples-sample size. Independent variables are gender, age, marital status, Educational qualification, occupation, and monthly income. The dependent variables are helpline for drug abuser, reason for drug abuse, emotional problems, accidents, brain damage, risky sex, and diseases. Independent sample $\mathrm{t}$ test, chi square, and ANOVA are the research tools used in this research.

\section{ANALYSIS AND DISCUSSION}

NULL HYPOTHESIS (HO): There is no significant difference between the helpline for drug abuser's and the gender

ALTERNATIVE HYPOTHESIS (H1): There is significant difference between the helpline for drug abuser's and the gender

Table 1: Awareness of Helpline for Drug Abuser's and Gender
\begin{tabular}{|l|r|r|r|r|}
\hline Gender & \multicolumn{1}{|c|}{ N } & Mean & Std. Deviation & $\begin{array}{c}\text { Std. Error } \\
\text { Mean }\end{array}$ \\
\hline Male & 1064 & 1.21 & .410 & .013 \\
\hline Female & 576 & 1.25 & .435 & .018 \\
\hline
\end{tabular}

Table 2: Independent Samples Test - Awareness of Helpline for Drug Abuser's and Gender

\begin{tabular}{|l|r|r|r|}
\hline & $\mathrm{t}$ & $\mathrm{df}$ & $\begin{array}{c}\text { Sig. (2- } \\
\text { tailed) }\end{array}$ \\
\hline Independent Samplet test & 1.851 & 1638 & .064 \\
\hline
\end{tabular}

$\begin{array}{llll}\text { Independent Sample t test } \quad & 1.851 & 1638 \quad .064\end{array}$

Since $\mathrm{p}$ value $(0.064)$ is not less than 0.05 null hypothesis is accepted. Therefore, there is no significant difference between the helpline for drug abuser's and the gender. It shows that awareness of helpline for drug abuser's depends on the gender

NULL HYPOTHESIS (HO): There is no significant association between major reason for drug abuse and age of the respondents

ALTERNATIVE HYPOTHESIS (H1): There is significant association between major reason for drug abuse and age of the respondents
Table 3: Cross Tabulation - Reason for Drug Abuse among Youngsters and Age

\begin{tabular}{|l|r|r|r|r|}
\hline \multirow{2}{*}{ Age } & \multicolumn{3}{|c|}{8.2 Reason for Drug Abuse among } & \multirow{2}{*}{ Youngsters } \\
\cline { 2 - 5 } & \multicolumn{3}{|c|}{ Total } \\
\cline { 2 - 5 } Less than 25 years & 165 & 336 & 84 & 585 \\
\hline 26-35 years & 182 & 206 & 79 & 467 \\
\hline $36-45$ years & 118 & 202 & 80 & 400 \\
\hline $46-60$ years & 22 & 94 & 40 & 156 \\
\hline Above 60 years & 3 & 21 & 8 & 32 \\
\hline Total & 490 & 859 & 291 & 1640 \\
\hline
\end{tabular}

Table 4: Chi-Square Tests - Reason for Drug Abuse among Youngsters and Age

\begin{tabular}{|l|r|r|r|}
\hline & Value & \multicolumn{1}{|c|}{ df } & $\begin{array}{c}\text { Asymp. Sig. } \\
\text { (2-sided) }\end{array}$ \\
\hline Pearson Chi-Square & 54.668 & 8 & .000 \\
\hline
\end{tabular}

Since $\mathrm{p}$ value $(0.000)$ is less than 0.05 null hypothesis is rejected. Therefore, there is a significant association between major reason for drug abuse and age of the respondents. It shows that reason for drug abuse depends on the age.

NULL HYPOTHESIS (HO): There is no significant difference in the mean scores of level of agree ability towards effects of drought abuse among the effects of drug abuse among the educational qualification groups.

ALTERNATIVE HYPOTHESIS (H1): There is significant difference in the mean scores of level of agree ability towards effects of drought abuse among the effects of drug abuse among the educational qualification groups.

Table 5: ANOVA - Effects of Drug Abuse among Youngsters and Educational Qualification \& Results

\begin{tabular}{|c|c|c|c|c|c|c|}
\hline & & $\begin{array}{l}\text { Sum of } \\
\text { Squares }\end{array}$ & df & Mean Square & F & Sig. \\
\hline \multirow[t]{3}{*}{ Emotional Problems } & $\begin{array}{l}\text { Between } \\
\text { Groups }\end{array}$ & 10.237 & 4 & 2.559 & 2.987 & .018 \\
\hline & Within Groups & 1400.733 & 1635 & .857 & & \\
\hline & \begin{tabular}{|l|l|} 
Total \\
\end{tabular} & 1410.970 & 1639 & & & \\
\hline \multirow[t]{3}{*}{ Accidents } & $\begin{array}{l}\text { Between } \\
\text { Groups }\end{array}$ & 4.268 & 4 & 1.067 & 1.457 & .213 \\
\hline & Within Groups & 1197.604 & 1635 & .732 & & \\
\hline & \begin{tabular}{|l|} 
Total \\
\end{tabular} & 1201.873 & 1639 & & & \\
\hline \multirow[t]{3}{*}{ Brain Damage } & \begin{tabular}{|l|} 
Between \\
Groups
\end{tabular} & 11.576 & 4 & 2.894 & 3.027 & .0 \\
\hline & Within Groups & 1562.911 & 1635 & .956 & & \\
\hline & Total & 1574.487 & 1639 & & & \\
\hline \multirow[t]{3}{*}{ Risky Sex } & \begin{tabular}{|l|} 
Between \\
Groups
\end{tabular} & 18.474 & 4 & 4.619 & 5.594 & .0 \\
\hline & Within Groups & 1349.914 & 1635 & .826 & & \\
\hline & \begin{tabular}{|l|l|} 
Total \\
\end{tabular} & 1368.388 & 1639 & & & \\
\hline \multirow[t]{3}{*}{ Diseases } & $\begin{array}{l}\text { Between } \\
\text { Groups }\end{array}$ & 21.945 & 4 & 5.486 & 4.570 & .00 \\
\hline & Within Groups & 1962.931 & 1635 & 1.201 & & \\
\hline & \begin{tabular}{|l|l|} 
Total \\
\end{tabular} & 1984.876 & 1639 & & & \\
\hline
\end{tabular}

Since $\mathrm{p}$ value is less than 0.05 for Emotional problems, brain damage, risky sex, diseases, null hypothesis is rejected for that four aspects. Therefore, there is a significant difference in the mean scores of level of agreeability towards effects of drug abuse among the educational qualification groups. It shows that the effects of drug abuse depend on the educational qualification. 


\section{CONCLUSION}

The youngsters needed is educate and counsel young children and adolescents and create awareness among the public regarding drug abuse. Drug abuse is a very common and serious problem associated with health and social problems which are associated with complications. The beginning of drug abuse at early adolescence results in continuation of drug to the adulthood. Therefore, preventive programs are required to be divided decided and recommended for drug abuse. More studies on drug abuse are required to be done in India to see the current situation and to know the solutions for this situation. As most of the studies are either done on small scale on children, this is the demand for the bright future of the nation.

\section{REFERENCES}

1. Abuse, U. S. Department of Health And Human Services; National Institute on Drug, and US Department of Health and Human Services; National Institute on Drug Abuse. 2004. "Prevention Program Curbs Drug Abuse Among Middle-School Youth." PsycEXTRA Dataset. https://doi.org/10.1037/e493042006-003.

2. Abuse, U. S. Department of Health \&. Human Services; National Institute on Drug, and US Department of Health \& Human Services; National Institute on Drug Abuse. 2002. "Inhalant Abuse Among Young People." PsycEXTRA Dataset. https://doi.org/10.1037/e300492003-013.

3. Ashery, Rebecca Sager, Elizabeth B. Robertson, and Karol Linda Kumpfer. 1998. Drug Abuse Prevention Through Family Interventions. DIANE Publishing.

4. Baratvand, Mahmood, Mansour Soodani, Eghbal Zarei, and Abdolrahim Asadollahi. 2013. "Sexual Abuse and Drug Abuse Among Homeless Children in Ahvaz, Iran." Child Abuse Review. https://doi.org/10.1002/car.2263.

5. Beatty, Lula A., and US Department of Health and Human Services; National Institute on Drug Abuse. 1997. "Introduction: Drug Abuse Among Rural Ethnic and Migrant Populations." PsycEXTRA Dataset. https://doi.org/10.1037/e495612006-019.

6. Beschner, George M. 1979. Youth Drug Abuse: Problems, Issues, and Treatment. Free Press.

7. Beschner, George M., and Alfred S. Friedman. 1986. Teen Drug Use. Free Press.

8. Brizer, David A. 1993. "Religiosity and Drug Abuse among Psychiatric Inpatients." The American Journal of Drug and Alcohol Abuse. https://doi.org/10.3109/00952999309001623.

9. Burt, Marvin R. 1981. "Prevalence and Consequences of Drug Abuse among U.S. Military Personnel: 1980." The American Journal of Drug and Alcohol Abuse. https://doi.org/10.3109/00952998109016928.

10. Castillo, Kassandra. 2009. The Causes That Lead Teenagers to Drug and Alcohol Abuse. GRIN Verlag.

11. Cox, Terrence Charles, and Addiction Research Foundation of Ontario. 1983. Drugs and Drug Abuse: A Reference Text.

12. Dhawan, B. N., and US Department of Health and Human Services; National Institute on Drug Abuse.1987. "Drug Abuse in India: Progress in Research." PsycEXTRA

Dataset. https://doi.org/10.1037/e496672006-016.

13. Dube, K. C. 1972. "Patterns of Drug Abuse in India." Drug Abuse. https://doi.org/10.1007/978-1-4684-32107_13.

14. Fodor Miklós, and Sófi Gyula. 2015. "[The dangers of drug career in young people]." Orvosi hetilap 156 (46): 1843-46.
15. Global Youth Network, United Nations Office on Drugs and Crime, and World Health Organization. 2006. Monitoring and Evaluating Youth Substance Abuse Prevention Programmes. United Nations Publications.

16. Grabowski, John. 1994. Cocaine: Pharmacology, Effects, and Treatment of Abuse. DIANE Publishing.

17. Institute of Medicine, and Committee on Opportunities in Drug Abuse Research. 1996. Pathways of Addiction: Opportunities in Drug Abuse Research. National Academies Press.

18. Md, National Institute on Drug Abuse Div of Resource Development Hew Alcohol Drug Abuse \&. Mental Health Administration Rockville, National Institute on Drug Abuse, Div of Resource Development, HEW, Alcohol, Drug Abuse \& Mental Health Administration, and Rockville. 1978. "Phencyclidine Use among Youths in Drug Abuse Treatment." PsycEXTRA Dataset. https://doi.org/10.1037/e447212004-001.

19. Nelson, David Erik. 2010. Teen Drug Abuse. Greenhaven Press, Incorporated.

20. Schydlower, Manuel, and Rodolfo M. Arredondo. 2006 Substance Abuse Among Adolescents. W B Saunders Company.

21. "Smoking Habit among Youngsters." 2018. Journal of Addiction and Prevention. https://doi.org/10.13188/23302178.1000042 .

22. Trevino, Roberto A., and Alan J. Richard. 2002. "Attitudes towards Drug Legalization among Drug Users." The American Journal of Drug and Alcohol Abuse. https://doi.org/10.1081/ada-120001283.

23. United Nations Office on Drugs and Crime. 2004 Schools: School-Based Education for Drug Abuse Prevention. United Nations Publications.

24. Waters, Rosa. 2014. Alcohol \& Tobacco. Simon and Schuster. 